\title{
LITERATURA E ESTÉTICA, HOJE
}

Este número da Remate de Males propôs, em sua ementa, uma reflexão contemporânea sobre a arte. Partindo da problematização colocada por Adorno, cuja estética representa uma tentativa radical de construir uma teoria abrangente, dialeticamente clássica, da obra de arte - e, por decorrência, da literatura -, podemos considerar o texto artístico como um enigma sem solução. Entretanto, se de um lado a sua ideia do artefato estético como esperança diante da opressão social aparenta ser hoje resíduo de uma época e de uma forma de pensamento historicamente superadas, de outro seria possível identificar elementos atuais que dariam novo fôlego para uma nova relevância de sistematizações como a de Adorno. Os textos que responderam ao chamado da revista oferecem ricas considerações a respeito dessa problemática.

Refletindo sobre a questão proposta, Gianluca Bonaiuti, no seu artigo "Onde o signo se dissolve na sombra. A escrita da teoria depois de Adorno", afirma que a definição da forma literária é a chave de acesso à estética de Adorno, cuja concepção literária da arte contém um profundo significado humanista. Entretanto, diz o ensaio, as condições dessa definição dependem da estrutura midiática da sociedade da qual ela trata, o que implica uma mudança, dado que as estéticas atuais não são mais conduzidas pelo mesmo esforço como resultado da própria mídia. Markus Lasch, em "Sobre a atualidade de uma categoria estética: considerações a partir do estatuto de tragédia e trágico em Adorno", parte dos pensamentos deste autor, de Peter Szondi e de Christoph Menke, para refletir sobre a atualidade da categoria estética do trágico, considerando que, sob a aparente hibernação da práxis literária trágica, subsiste uma possível continuidade na perspectiva teórico-crítica, assim como uma correlação 
entre esses dois aspectos. O texto de Robert Hullot-Kentor, "Moishe Postone e o ensaio como forma”, traduzido por Tauan Tinti, estabelece relações entre as obras deste autor e a de Theodor Adorno por meio da ideia do "ensaio como forma", explorando em especial a incompatibilidade entre suas abordagens, que gira principalmente em torno das posições divergentes de ambos com relação à crítica imanente.

Saindo do âmbito da Escola de Frankfurt, André Cechinel, no ensaio "Reconfigurações ético-reparadoras do literário hoje", analisa os indícios de uma função ético-reparadora na literatura e nos estudos literários atuais, que podem aparecer em dois momentos fundamentais, a saber: a) a literatura do século XX é apresentada sob o ângulo de uma suposta negatividade ou intransitividade radical, capaz de "desobrar a obra" em sua "estética da supressão"; b) partindo de um debate introdutório sobre alguns dos lugares de transitividade vislumbrados para a literatura atual, vê-se que o literário adquire a função de um campo ético-reparador, responsável por "dar visibilidade", "lembrar", "reparar danos", "confortar" etc. Já Kelvin Falcão Klein, no artigo "Dissolução do estético e resistência: da parataxe ao terceiro continente”, propõe uma reflexão teórica acerca das relações possíveis entre o estilo paratático e a estética, compreendida como disciplina e horizonte de experimentação artística. A partir de uma série de autores, Klein considera que o estilo paratático é mobilizado como dispositivo de resistência à dissolução do estético, organizado a partir de três linhas de fuga simultâneas e complementares: preocupação com a montagem (de temporalidades e referências); reivindicação de um presente instável (um ponto de vista contingente que recusa a totalidade); $\mathrm{e}$ abertura da cronologia em prol de uma fabricação da história (como defesa da dimensão plástica e maleável do próprio devir histórico). Wanderlan Alves, por sua vez, em "Pós-autonomia e crítica menor", investiga a possibilidade, para a crítica, da noção de pós-autonomia desenvolvida por Ludmer, noção que questiona parâmetros, valores e práticas institucionais eacadêmicos para o literário. Haveria, de modo paradoxal, a necessidade de uma crítica pós-autônoma instalar-se à margem da instituição literária, a fim de se promover uma leitura crítica das institucionalizações do literário - pois, caso contrário, essas hipóteses acerca da pós-autonomia correm o risco de "cair num vazio de sentido", que as reduziria a mera performance ou espetáculo. Fechando essa segunda seção de artigos, Alfredo Suppía, em "O argumento da simulação e seu caldo de cultura", propõe uma revisão do argumento da simulação de Nick Bostrom, sob uma perspectiva 
cultural e multimidiática, com o objetivo de discutir eventuais influências culturais e ideológicas no desenvolvimento do argumento original. Parte da hipótese de que todo o argumento de Bostrom está tão contaminado por um "caldo de cultura" (midiático, metafísico, político e econômico) que é difícil confirmar o distanciamento que se espera de uma reflexão filosófica de tal monta. Fica, então, a pergunta se o argumento de Bostrom não constitui um subproduto de tal "caldo de cultura", não sendo, afinal, mais uma manifestação superestrutural na esteira de sistema de produção pós-industrial de extrema acumulação de capital financeiro.

O terceiro grupo temático do volume inclui dois textos com foco mais direto sobre literatura. William Eduardo Righini de Souza, no artigo intitulado "A sociabilidade literária na França dos séculos XVIII e XIX: salões, cenáculos, círculos e cafés”, considera que, embora todos esses espaços tenham sido importantes para a formação e consagração de autores, eles possuíam distinções, por exemplo quanto à participação de mulheres, ao modelo das discussões promovidas e à relação entre o público e o privado. Finalmente, refletindo sobre o romance de Bernardo Kucinski, "Feche a porta atrás de si: a memória e o horror em K.", Danielle dos Santos Barbosa, em chave psicanalítica, julga que a obra apresenta, em um exercício de narrador presente, a relação entre dualidades: os dois narradores possíveis - o autor Kucinski e o pai K. -, a relação entre lembrar e esquecer, entre memória e reminiscência e a movimentação cíclica entre luto e culpa, proporcionada pelo ciclo de vida e morte que perpassa a narração dos fatos e ações em contextos de experiência da violência institucional. Tal violência é, afinal, o caráter autoritário da ditadura brasileira, a qual apresenta elementos que permitem localizar aspectos narcísicos e relacionados com o Complexo de Édipo não resolvido e a transposição do recalcado para a esfera pública.

Este número da Remate de Males abre uma secção dedicada a traduções, e o presente número traz, pelo trabalho de Bruno Reiser, o luminoso ensaio de Georges Bataille, "A estrutura psicológica do fascismo". Para o escritor e pensador francês, a descrição psicológica da sociedade deve começar pela parte mais acessível ao conhecimento, cujo caráter significativo é a homogeneidade tendencial, ou seja, a comensurabilidade dos elementos e da consciência dessa comensurabilidade, que revelam que as relações humanas podem ser mantidas por uma redução a regras fixas baseadas na consciência da identidade possível de pessoas e de situações definidas - o que excluiria toda violência do curso da existência. 
A Remate de Males traz também uma entrevista de Camila Peruchi com Auritro Majumder, autor de Insurgent Imaginations: World Literature and the Periphery (2021). A matéria traz por título "A periferia contra-ataca: entrevista com Auritro Majumder", na qual o autor considera a existência de uma aposta em duas esferas da vida que, hoje em dia, são com frequência subestimadas e, do ponto de vista investigativo, raramente reunidas com êxito: a imaginação e a luta pela libertação.

Nosso volume encerra-se com uma generosa seção de resenhas. Joyce Silva Fernandes resenhou o Livro Trauma, de Lucy Bond e Stef Craps, obra que se apresenta como um guia necessário para a compreensão da elasticidade do termo trauma e de sua aplicabilidade para os estudos culturais e literários, considerando-se inclusive sua atualidade, dado que o século XX foi marcado por uma quantidade única de catástrofes humanas. Já Larissa Costa da Mata, em "Negritude e criação como devir no pós-colonialismo, segundo Souleymane Bachir Diagne”, apresenta o livro Bergson pós-colonial. O elã vital no pensamento de Léopold Sédar Senghor e Muhammad Iqbal, no qual o filósofo senegalês investiga como a duração, o vitalismo e a intuição do autor de Matéria e memória levaram dois intelectuais distintos, Léopold Sédar Senghor e Muhammad Iqbal, a reverem a identidade como uma categoria fixa e o Islã como uma religião estagnada, respectivamente.

Wibsson Ribeiro Lopes resenhou a obra de Josh Robinson, Adorno's Poetics Of Form, que investiga o conceito adorniano de forma, considerando que o modo como a própria apresentação do que Adorno entende como forma já é em si uma maneira de se aproximar do conceito. Yuri Brunello e Bárbara Costa Ribeiro, por sua vez, resenharam o livro de Fabio Akcelrud Durão, Metodologia de pesquisa em literatura, obra que reflete sobre o processo de pesquisa em literatura, hoje, no Brasil, assim como sobre o próprio espaço que a literatura ocupa na academia. Por fim, Jorge Vicente Valentim resenhou a obra Modernismos em modernidades incipientes: Mário de Andrade e Almada Negreiros, de Daniel Marinho Laks, e a essa resenha intitulou "De como o ensaio pode ser um engate ou um ménage à trois (ou mais, a depender do gosto do leitor)”. Essa obra de Laks constitui um ensaio que exaure tanto os campos conceituais quanto os teóricos, com um alentado olhar sobre as obras de Mario de Andrade e Almada Negreiros. Reflete sobre a importância da presença desses dois escritores seminais nas literaturas brasileira e portuguesa, a partir de suas inserções em correntes estéticas dos modernismos nas duas margens 
do Atlântico e em contextos socioculturais ainda demarcados por uma profunda incipiência no tocante aos projetos políticos de entrada do Brasil e de Portugal numa efetiva aventura da modernidade.

Fabio Akcelrud Durão 